\title{
Transscleral diode laser in the treatment of retinopathy of prematurity
}

\begin{abstract}
Purpose To assess the outcome of contact transscleral diode laser (TSDL) in the treatment of threshold retinopathy of prematurity (ROP).

Method TSDL was performed in 14 eyes of 8 babies who presented to the paediatric ophthalmic service at King's College Hospital between 1996 and 1997 with threshold ROP (median post-conceptual age $26+1$ weeks, median birthweight $835 \mathrm{~g}$ ) by a single surgeon. Follow-up ranged from 9 to 41 weeks (median 21 weeks).

Results In 11 eyes (79\%) regression of ROP occurred after a single laser treatment with a good anatomical outcome. In 3 eyes (21\%) there was an unfavourable response with the development of traction retinal detachment. These include both eyes of one baby who rapidly progressed to stage IV ROP. One other eye developed a fibrotic band a few months after treatment. No significant complications of laser treatment were observed.

Conclusion These initial results indicate that TSDL photocoagulation is an effective and technically straightforward alternative to cryotherapy in the treatment of ROP.
\end{abstract}

Key words Laser indirect ophthalmoscopy, Retinopathy of prematurity, Transscleral diode laser

Retinopathy of prematurity (ROP) is a leading cause of childhood blindness in industrialised countries, and the standard treatment for threshold disease (defined as stage III+ disease involving five contiguous or eight cumulative clock-hours in zone 1 or 2) is transscleral cryotherapy to the avascular retina anterior to the ridge. The multicentre North American Cryotherapy for Retinopathy of Prematurity study has reported the long-term safety and efficacy of cryotherapy in preventing blindness in these babies, incidence of blindness being reduced from $48 \%$ to $31.5 \%{ }^{1}$ Guidelines for the screening and treatment have been developed by the Royal College of Ophthalmologists. ${ }^{2}$
Cryotherapy treatment is associated with significant ocular inflammation, ${ }^{3}$ choroidal damage and breakdown of the blood-retinal barrier. ${ }^{4,5}$ The development of semiconductor diode lasers (wavelength emission, 790-840 nm) has led to an alternative strategy for the treatment of $\mathrm{ROP},{ }^{6,7}$ with a reduced incidence of complications being reported. Currently, diode laser photocoagulation is largely delivered using the indirect ophthalmoscope $\left(\mathrm{LIO}^{6-10}\right)$. Effective treatment produced by the LIO may, therefore, be limited by media opacities and small pupil size. We present our initial findings using the transsceral diode laser (TSDL) in the treatment of threshold ROP.

\section{Method}

Babies who presented to the paediatric ophthalmic service at King's College Hospital between 1996 and 1997 with threshold ROP (stage III+) and babies who had not reached 5 clock-hours of contiguous new vessels but had at least 3 clock-hours of new vessels with advanced plus disease (cloudy media or iris rigidity) were treated with TSDL to the peripheral retina anterior to the ridge by a single surgeon (W.A.). All treatment was transconjunctival. Treatments were performed using a semiconductor diode laser, with an emission wavelength of $810 \mathrm{~nm}$ (Iris Medical Instruments, Mountain View, CA). The maximum available power was $2 \mathrm{~W}$ and the exposure duration could be incrementally increased up to a maximum of $9 \mathrm{~s}$. Laser delivery was accomplished via a transsceral probe, which was applied to the external scleral surface (Fig. 1). A transilluminating red

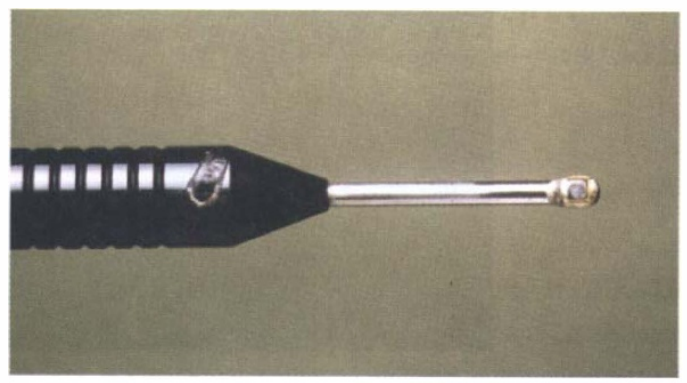

Fig. 1. Transscleral diode laser probe.

\author{
A.R. Davis \\ H. Jackson \\ J.D.A. McHugh \\ W.A. Aclimandos \\ King's College Hospital \\ London, UK \\ D. Trew \\ Farnborough Hospital \\ Farnborough \\ Kent, UK
}

Mr W.A. Aclimandos Eye Department

King's College Hospital Denmark Hill

London SE5 9RS, UK

Tel: +44 (0)171346 3534

Fax: $+44(0) 1713463738$

Proprietary interest: none

Received: 11 February 1998 Accepted in revised form: 25 March 1999 


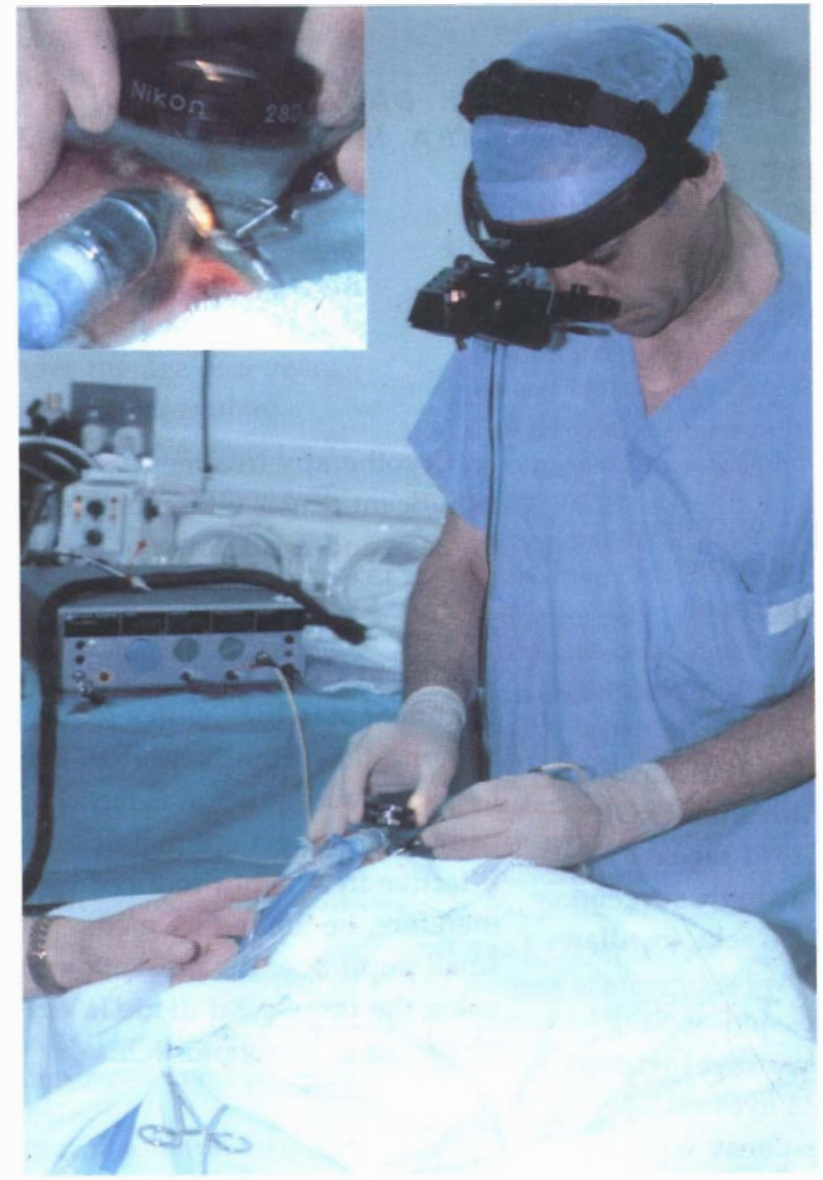

Fig. 2. Viewing the transscleral diode laser indentation of the peripheral retina.

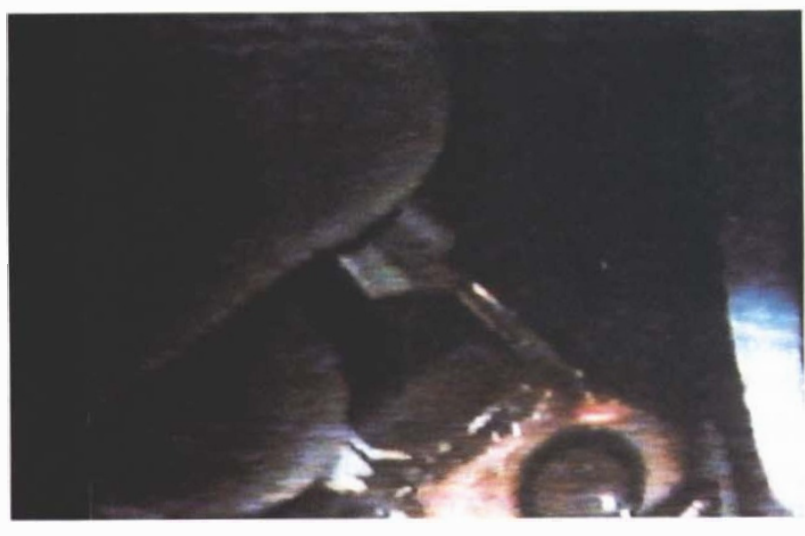

Fig. 3. Transscleral diode laser probe with red emitting aiming beam.

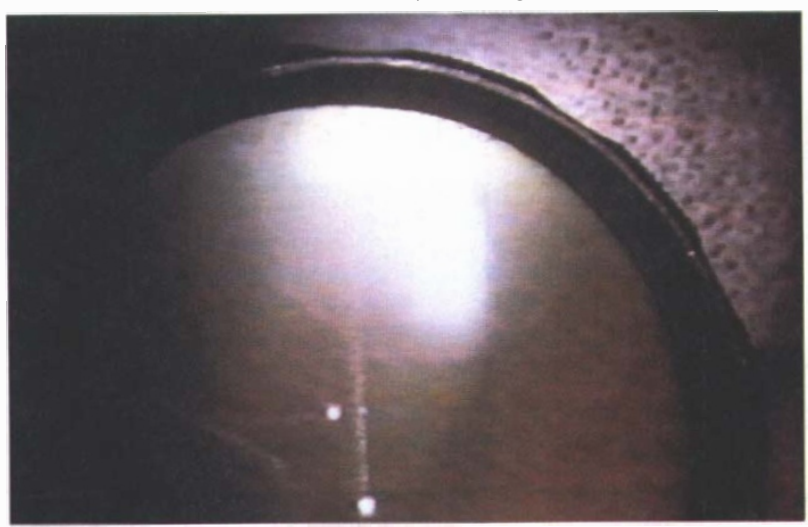

Fig. 5. Area of laser reaction of transscleral diode laser photocoagulation. photocoagulation.

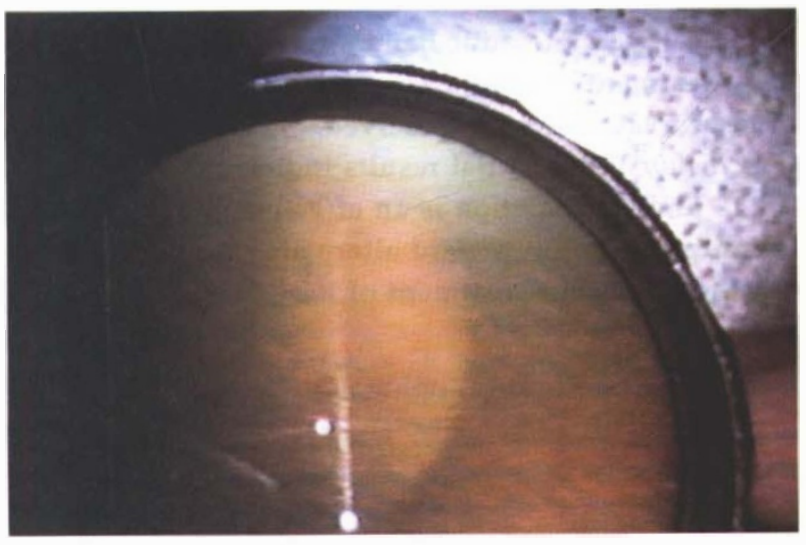

Fig. 4. Area of indentation of transscleral diode laser 


\begin{tabular}{|c|c|c|c|c|c|c|c|c|}
\hline \multirow{2}{*}{$\begin{array}{c}\text { Patient } \\
\text { no. }\end{array}$} & \multirow{2}{*}{$\begin{array}{l}\text { Post-conceptual } \\
\text { age at birth } \\
\text { (weeks + days) }\end{array}$} & \multirow{2}{*}{$\begin{array}{l}\text { Birth- } \\
\text { weight } \\
\text { (g) }\end{array}$} & \multirow{2}{*}{$\begin{array}{c}\text { Prenatal } \\
\text { complications }\end{array}$} & \multirow{2}{*}{$\begin{array}{c}\text { Postnatal } \\
\text { complications }\end{array}$} & \multicolumn{2}{|c|}{$\begin{array}{l}\text { Ocular appearance } \\
\text { before treatment }\end{array}$} & \multicolumn{2}{|c|}{ Disease severity } \\
\hline & & & & & Right eye & Left eye & Right eye & Left eye \\
\hline 1 & $27+4$ & 908 & Severe IUGR & $\begin{array}{l}\text { RDS, inguinal } \\
\text { hernia repair }\end{array}$ & $\begin{array}{c}\text { III+, } \\
\text { vitreous } \\
\text { haemorrhage }\end{array}$ & NAD & $\begin{array}{l}4 \text { clock-hours } \\
\text { (contiguous) } \\
\text { zone } 2\end{array}$ & NAD \\
\hline 2 & 27 & 1120 & Nil & $\begin{array}{l}\text { Ventilation } 2 \text { days, } \\
\text { in oxygen } 9 \text { weeks }\end{array}$ & III+ & $\begin{array}{c}\text { Vitreous } \\
\text { haemorrhage }\end{array}$ & $\begin{array}{l}6 \text { clock-hours } \\
\text { (contiguous), } \\
\text { zone } 2 \text { with } \\
\text { haemorrhage }\end{array}$ & $\begin{array}{c}3 \text { clock-hours } \\
\text { (non- } \\
\text { contiguous), } \\
\text { zones } 1 \text { and } 2\end{array}$ \\
\hline 3 & $24+5$ & 710 & Nil & $\begin{array}{l}\text { RDS, septicaemia, } \\
\text { anaemia, IVH }\end{array}$ & III+ & III+ & $\begin{array}{l}5 \text { clock-hours } \\
\text { (contiguous), } \\
\text { zones } 1 \text { and } 2\end{array}$ & $\begin{array}{c}5 \text { clock-hours } \\
\text { (contiguous), } \\
\text { zone } 2\end{array}$ \\
\hline 4 & 25 & 780 & Nil & $\begin{array}{c}\text { Hypotensive, DIC, } \\
\text { septicaemia, IVH, } \\
\text { ischaemic foot }\end{array}$ & III+ & III+ & $\begin{array}{c}6 \text { clock-hours } \\
\text { (contiguous) } \\
\text { zone } 1\end{array}$ & $\begin{array}{l}5 \text { clock-hours } \\
\text { (contiguous), } \\
\text { zones } 1 \text { and } 2\end{array}$ \\
\hline 5 & $28+3$ & 1200 & Nil & $\begin{array}{c}\text { Pneumothorax, } \\
\text { septicaemia, PPH, } \\
\text { PDA, upper GI bleed }\end{array}$ & III+ & $\begin{array}{l}\text { II with plus } \\
\text { disease }\end{array}$ & $\begin{array}{l}4 \text { clock-hours } \\
\text { (non- } \\
\text { contiguous), } \\
\text { zone } 2\end{array}$ & $\begin{array}{l}3 \text { clock-hours } \\
\text { zones } 1 \text { and } 2\end{array}$ \\
\hline 6 & 25 & 650 & Nil & RDS, PDA & III+ & III+ & $\begin{array}{l}3 \text { clock-hours } \\
\text { (contiguous), } \\
\text { zones } 1 \text { and } 2\end{array}$ & $\begin{array}{l}3 \text { clock-hours } \\
\text { (contiguous), } \\
\text { zones } 1 \text { and } 2\end{array}$ \\
\hline 7 & $26+5$ & 890 & $\begin{array}{l}\text { Twin donor of } \\
\text { twin-to-twin } \\
\text { transfusion }\end{array}$ & $\begin{array}{c}\text { RDS, PDA, } \\
\text { septicaemia, } \\
\text { bradycardia, unstable } \\
\text { respiration }\end{array}$ & III+ & III+ & $\begin{array}{l}5 \text { clock-hours } \\
\text { (contiguous), } \\
\text { zone } 1 \text { and } 2\end{array}$ & $\begin{array}{l}5 \text { clock-hours } \\
\text { (contiguous), } \\
\text { zone } 1 \text { and } 2\end{array}$ \\
\hline 8 & $25+4$ & 680 & $\begin{array}{l}\text { Maternal pre- } \\
\text { eclampsia }\end{array}$ & $\begin{array}{c}\text { Bronchopulmonary } \\
\text { dysplasia }\end{array}$ & III+ & III+ & $\begin{array}{c}4 \text { clock-hours } \\
\text { (contiguous), } \\
\text { zone } 2\end{array}$ & $\begin{array}{c}5 \text { clock-hours } \\
\text { (contiguous), } \\
\text { zones } 1 \text { and } 2\end{array}$ \\
\hline
\end{tabular}

IUGR, intrauterine growth retardation; RDS, respiratory distress syndrome: IVH, intraventricular haemorrhage; DIC, disseminated intravascular coagulation; PPH, persistent pulmonary hypertension; PDA, patent ductus arteriosus; GI, gastrointestinal; NAD, no abormality detected; iqr, interquartile range.

emitting diode aiming beam allows the target area to be visualised with an indirect ophthalmoscope and precise treatment in the target area to be given. The laser is activated via a foot switch. The desired visible end-point is a greyish-white retinal lesion (Figs. 2-5). For a pulse duration of 2-3 s, powers of between 500 and $750 \mathrm{~mW}$ were employed (see Table 2). Retinal blanching could usually be seen even in the presence of vitreous haemorrhage. In none of the cases was it felt necessary to open the conjunctiva to achieve sufficient treatment of the avascular retina. Minimal chemosis and lid oedema were observed in all patients. Retinal burns appeared as pigmented scars 2 weeks after treatment. G-Predsol-N (Evans) or Oc-Betnesol-N (Evans) t.d.s. were given for 4 days following treatment.

\section{Patients}

The demographic details of the babies are shown in Table I. A total of 14 eyes in 8 babies were treated. All babies were born at less than 29 weeks post-gestational age with a median birth weight of $835 \mathrm{~g}$ (interquartile range 702.5$961 \mathrm{~g})$.

\section{Results}

Outcome following treatment is shown in Table 2. All 14 eyes showed regression of plus disease at 1 week after treatment. Twelve eyes began to show signs of regression of abnormal neovascularisation at 2 weeks. At 2 weeks 2 eyes in one baby showed rapid progression to stage IV ROP, despite initial regression of plus disease. This baby was treated at 35 weeks gestational age and at the time of treatment had very aggressive plus disease. One eye in another baby developed, a few months later, a preretinal fibrotic band extending from the disc to the temporal periphery. This subsequently caused a traction retinal detachment.

At most recent follow-up 11 eyes (79\%) showed a favourable outcome. Three eyes had developed traction retinal detachments.

\section{Discussion}

Cryotherapy for the treatment of retinopathy of prematurity has been shown to reduce the rate of an unfavourable structural outcome and to improve functional outcome. ${ }^{1,11-13}$ Data from the CRYOROP 


\begin{tabular}{|c|c|c|c|c|c|c|}
\hline \multirow{2}{*}{$\begin{array}{c}\text { Patient } \\
\text { no. }\end{array}$} & \multirow{2}{*}{$\begin{array}{l}\text { ost-conceptual age } \\
\text { at treatment } \\
\text { (weeks + days) }\end{array}$} & \multicolumn{2}{|c|}{ Treatment } & \multirow{2}{*}{$\begin{array}{l}\text { Outcome at } \\
1 \text { week }\end{array}$} & \multirow[b]{2}{*}{ Follow-up } & \multirow{2}{*}{$\begin{array}{l}\text { Length of } \\
\text { follow-up } \\
\text { (weeks) }\end{array}$} \\
\hline & & Right eye & Left eye & & & \\
\hline 1 & $40+4$ & $74 \times 700-750 \mathrm{~mW}$ & Nil & Regression & $\begin{array}{l}\text { Flat retina, no temporal } \\
\text { dragging right and left }\end{array}$ & 41 \\
\hline 2 & 39 & $100 \times 750 \mathrm{~mW}$ & $150 \times 750-1000 \mathrm{~mW}$ & $\begin{array}{l}\text { Regression right } \\
\text { and left, vitreous } \\
\text { haemorrhage left }\end{array}$ & $\begin{array}{c}\text { Right retina flat, no } \\
\text { temporal dragging, } \\
\text { left TRD }\end{array}$ & 31 \\
\hline 3 & $32+5$ & $307 \times 500 \mathrm{~mW}$ & $209 \times 500 \mathrm{~mW}$ & $\begin{array}{l}\text { Regression } \\
\text { right and left }\end{array}$ & $\begin{array}{l}\text { Flat retina no plus } \\
\text { disease right and left }\end{array}$ & 12 \\
\hline 4 & 34 & $103 \times 750 \mathrm{~mW}$ & $151 \times 750 \mathrm{~mW}$ & $\begin{array}{l}\text { Regression } \\
\text { right and left }\end{array}$ & $\begin{array}{c}\text { At } 2 \text { weeks developed } \\
\text { bilateral TRD }\end{array}$ & 20 \\
\hline 5 & $41+4$ & $90 \times 500 \mathrm{~mW}$ & Nil & Regression & $\begin{array}{l}\text { Flat retina, no } \\
\text { temporal dragging }\end{array}$ & 34 \\
\hline 6 & 37 & $121 \times 570-600 \mathrm{~mW}$ & $132 \times 570-600 \mathrm{~mW}$ & Regression & $\begin{array}{l}\text { Flat retina, no } \\
\text { temporal dragging }\end{array}$ & 22 \\
\hline 7 & $34+5$ & $55 \times 750 \mathrm{~mW}$ & $55 \times 750 \mathrm{~mW}$ & $\begin{array}{c}\text { Regression right, } \\
\text { vitreous haemorrhage } \\
\text { left }\end{array}$ & $\begin{array}{l}\text { Flat retina right } \\
\text { and left, vitreous } \\
\text { haemorrhage left }\end{array}$ & 9 \\
\hline 8 & $34+4$ & $200 \times 550 \mathrm{~mW}$ & $270 \times 550 \mathrm{~mW}$ & $\begin{array}{c}\text { Regression of plus } \\
\text { disease }\end{array}$ & $\begin{array}{l}\text { Flat retina, left mild } \\
\text { temporal dragging }\end{array}$ & 20 \\
\hline Median & 21 & & & & & \\
\hline iqr1 & 21 & & & & & \\
\hline iqr3 & 34 & & & & & \\
\hline
\end{tabular}

TRD, traction retinal detachment; iqr, interquartile range.

study ${ }^{1}$ have confirmed a reduction in blindness from $48 \%$ to $31.5 \%$ and in unfavourable retinal outcome from $45.4 \%$ to $26.9 \%$ with treatment. Fewer of the treated eyes $(13 \%)$ attained vision better than $6 / 12$ compared with control eyes $(17 \%)$ at 5.5 years, suggesting that whilst cryotherapy is beneficial overall, this may be at the cost of normal vision in some children. This could be related to the presence of macular abnormalities related to cryotherapy treatment. ${ }^{14}$

Laser indirect photocoagulation with argon and infrared diode lasers has provoked the development of alternative treatment strategies. Argon laser is essentially not portable because of size and weight. It also requires a greater energy output than diode laser to stimulate regression of ROP. ${ }^{15,16}$ In vitro studies have suggested that diode laser has advantages over cryotherapy. Diode laser produces a chorioretinal lesion that spares the inner retinal layers. Although there is destruction of the choriocapillaris, the larger choroidal vessels are spared. ${ }^{17}$ Using a transscleral delivery system $35-71 \%$ of diode laser energy is transmitted through the sclera and absorbed by melanin in the choroid and retinal pigment epithelium. ${ }^{18}$ TSDL produces a similar chorioretinal scar with preservation of large choroidal vessels. The scleral collagen underlying the lesions remains intact. ${ }^{19}$ In contrast cryotherapy produces large atrophic glial scar and destroys the chorioretinal architecture. ${ }^{5}$ Cryotherapy also produces a significant breakdown of the blood-retina barrier in comparison with diode laser. ${ }^{19}$

Diode laser delivered by an indirect system has been shown to be as effective as cryotherapy in the treatment of threshold ROP. ${ }^{6-10}$ In our group 11 of 14 eyes (79\%) showed a favourable outcome following treatment with
TSDL. This is comparable to the results described for LIO. Seiberth et al. ${ }^{20-22}$ report a success rate of $90-96 \%$ using TSDL, but had fewer babies with disease in zone 1. In our study, most babies with disease extending into zone 1 had some 'peninsula-like' areas of ischaemic retina beyond the reach of the transscleral probe. Treatment was applied as far back as possible but did not cover every peninsula of avascular retina. This was considered satisfactory on the basis that at least $70 \%$ of the avascular retina had been treated.

The baby in our study who continued to develop ROP despite treatment was first seen at 34 weeks and was treated at 35 weeks post-conceptual age. He had very aggressive plus disease at presentation. Despite initial regression of plus disease 2 weeks after treatment, traction retinal detachment developed. In a second baby a traction retinal detachment developed despite initial regression of neovascularisation. This eye developed a fibrous band extending from the disc to the temporal retinal periphery including the fovea, which subsequently caused a traction retinal detachment.

Side-effects of cryotherapy are well documented in the literature. There is almost universal conjunctival chemosis and lid oedema. ${ }^{3,8,10}$ This can make retreatment, if necessary, technically difficult. Usually the side-effects are transitory and do not affect visual development. A case has been reported of persistent conjunctival proliferation which affected a child's visual development at the age of 3 years. ${ }^{23}$ Other transient anterior segment complications include conjunctival haematoma, inadvertent conjunctival laceration and corneal clouding. Diode laser treatment delivered by a laser indirect ophthalmoscope is also associated with 
anterior segment complications. Lens burns have been described, as has the development of posterior synechiae. ${ }^{24}$ Of more concern is the possibility of iris clipping due to the large cone angle of some diode systems. ${ }^{25}$ A case of bilateral hyphaema secondary to iris trauma in a baby treated for ROP has been described. ${ }^{26}$ This baby had a widely dilated pupil. In our study none of the babies had significant anterior segment trauma. The degree of conjunctival oedema was minimal and resolved in $24 \mathrm{~h}$ in all cases. As TSDL is a contact system it is extremely unlikely that iris clipping could occur.

Posterior segment complications as a result of cryotherapy treatment include exudative detachment ${ }^{27}$ and macular coloboma and retinal pigment epithelium (RPE) abnormalities. ${ }^{16}$ The risk of posterior segment complications with diode laser is small as the majority of energy induced is absorbed at the level of the RPE.

Pigmentation of the RPE begins during the seventh postgestational week, but pigmentation of the choroid only occurs between 20 and 35 weeks gestational age. ${ }^{28}$ Thus the risk of choroidal damage in the premature eye with diode laser treatment is small. LIO has not been associated with choroidal haemorrhage and we had no cases of choroidal haemorrhage in our patients.

The diode laser is easily transportable and can be used in the special care baby unit. We have in one case taken the TSDL to the referral hospital and performed treatment on a baby without the necessity for transfer to King's College Hospital. Although LIO has been advocated as a procedure to be performed with sedation, ${ }^{9}$ other authors have preferred general anaesthetic. ${ }^{10}$ Our preferred method of anaesthesia for TSDL is general anaesthetic as this provides the optimal conditions required for treatment.

This pilot study suggests the efficacy and safety of the TSDL in the treatment of retinopathy of prematurity. The combination of transscleral and indirect laser may prove to be the ideal regimen for treatment of ROP, particularly in babies with extensive disease in zone 1 or those who need re-treatment. Further work is needed to confirm these findings and to determine the long-term functional outcome in these infants.

We would like to acknowledge the support of Mr A. Mcfarlane and Mr R. Edwards who have referred patients for treatment.

\section{References}

1. Cryotherapy for the Treatment of Retinopathy of Prematurity Co-operative group. Multicentre trial of cryotherapy for the treatment of ROP. Snellen acuity and structural outcome at $51 \frac{1}{2}$ years after randomisation. Arch Ophthalmol 1996;114:417-24.

2. Royal College of Ophthalmologists and British Association of Perinatal Medicine. Retinopathy of prematurity: guidelines for screening and treatment. London: Royal College of Ophthalmologists, 1995.

3. Cryotherapy for Retinopathy of Prematurity Co-operative Group. Multicentre trial of cryotherapy for retinopathy of prematurity: three month outcome. Arch Ophthalmol 1990;108:195-204.
4. Jaccoma EH, Conway BP, Campochiaro PA. Cryotherapy causes extensive breakdown of the blood retinal barrier: a comparison with argon laser photocoagulation. Arch Ophthalmol 1980;103:1728-30.

5. Vrabec TR, McNamara JA, Eagle RC, Tasman W. Cryotherapy for retinopathy of prematurity: a histological comparison of a treated and untreated eye. Ophthalmic Surg 1994;25:38-41.

6. Goggin M, O'Keefe M. Diode laser for retinopathy of prematurity: early outcome. Br J Ophthalmol 1993;77:559-62.

7. McNamara JA, Tasman W, Vander JF, Brown GC. Diode laser for retinopathy of prematurity: preliminary results. Arch Ophthalmol 1992;110:1714-6.

8. Hunter DG, Repka MX. Diode laser for retinopathy of prematurity: a randomised study. Ophthalmology 1995;100:238-44.

9. Seiberth V, Linderkamp O, Vardarii I, Knorz MC, Liesenhoff $\mathrm{H}$. Diode laser photocoagulation for stage $3+$ retinopathy of prematurity. Graefes Arch Clin Exp Ophthalmol 1995;233:489-93.

10. Ling CS, Fleck BW, Wright E, Anderson C, Laing I. Diode laser treatment of retinopathy of prematurity: structural and functional outcome. Br J Ophthalmol 1995;79:637-41.

11. Cryotherapy for Retinopathy of Prematurity Co-operative Group. Multicenter trial of cryotherapy for retinopathy of prematurity: preliminary results. Arch Ophthalmol 1988;106:471-9.

12. Cryotherapy for Retinopathy of Prematurity Co-operative Group. Multicenter trial of cryotherapy for retinopathy of prematurity: $3 \frac{1}{2}$ year outcome. Structure and function. Arch Ophthalmol 1993;111:339-44.

13. Robinson R, O'Keefe M. Cryotherapy for retinopathy of prematurity: a prospective study. Br J Ophthalmol 1992;72:289-91.

14. Saito Y, Hatsukawa Y, Micel Lewis J, Koike H, Omoto T, Tano Y. Macular coloboma-like lesions and pigment abnormalities as complications of retinopathy of prematurity in very low birth weight infants. Am J Ophthalmol 1996;122:299-308.

15. McNamara JA, Tasman W, Brown GC, Federman JL. Laser photocoagulation for stage $3+$ retinopathy of prematurity. Ophthalmology 1991;98:576-80.

16. Benner JD, Morse LS, Hay A, Landers MB. A comparison of argon and diode photocoagulation combined with supplemental oxygen for the treatment of retinopathy of prematurity. Retina 1993;13:222-9.

17. McHugh JDA, Marshall J, fftyche TJ, Hamilton AM, Raen A. Macular photocoagulation of human retina with a diode laser: a comparative histopathological study. Lasers Light Ophthalmol 1990;3:11-28.

18. Obana A, Lorenz B, Birngruber R. Transscleral and indirect ophthalmoscope diode laser retinal photocoagulation: experimental quantification of the therapeutic range for their application in the treatment of retinopathy of prematurity. Graefes Arch Clin Exp Ophthalmol 1993;231:378-83.

19. Jennings $T$, Fuller T, Vaklich J, Lam TT, Joondepth BC, Ticho B, et al. Transscleral contact retinal photocoagulation with an $810 \mathrm{~nm}$ semiconductor diode laser. Ophthalmic Surg 1990;21:492-6.

20. Seiberth V, Vardarii W, Jendritza MC, Knorz MC, Leisenhoff $\mathrm{H}$. Transscleral versus transpupillary diode laser for threshold retinopathy of prematurity. Invest Ophthalmol Vis Sci 1996;37(Suppl):3176.

21. Seiberth V, Vardarii W, Jendritza MC, Knorz MC, Leisenhoff H. Transscleral versus transpupillary diode laser photocoagulation for stage III+ retinopathy of prematurity. German J Ophthalmol 1995;1(Suppl):127.

22. Seiberth V, LinderKamp MD, Vardali I. Transscleral versus transpupillary diode laser photocoagulation for treatment of threshold retinopathy of prematurity. Arch Ophthalmol 1997;115:1270-5. 
23. Watanabe H, Tsukamoto Y, Saito Y, Maeda N, Kiritoshi A, Shimomura Y. Massive proliferation of conjunctival tissue after cryotherapy for retinopathy of prematurity. Arch Ophthalmol 1997;115:278-9.

24. Capone A, Drack AV. Transient lens changes after diode laser retinal photoablation for retinopathy of prematurity. Am J Ophthalmol 1994;118:533-5.

25. Woon WH, ffyche TJ, Hamilton AMP. Iris clipping with the diode laser when performing retinal photocoagulation. $\mathrm{Br} \mathrm{J}$ Ophthalmol 1991;75:386-90.
26. Rundle P, McGinity FG. Bilateral hyphema following diode laser for retinopathy of prematurity. Br J Ophthalmol 1995;79:1055-6.

27. Vurkner G, Brod R. Presumed exudative retinal detachment after cryotherapy in retinopathy of prematurity. Ann Ophthalmol 1992;24:175-6.

28. Mann IDA. The development of the human eye. London: BMA, 1949:197-201. 